\title{
Non-matrix-matched analysis of $\mathbf{U}$ - $\mathrm{Th}-\mathrm{Pb}$ ages of accessory minerals by LA-ICP-MS - IAG Young Scientist Medal Lecture
}

TAO LUO AND ZHAOCHU HU

China University of Geosciences, Wuhan

Presenting Author: 466096427@qq.com

The U-Th-Pb geochronologic analysis of accessory minerals has played an important role in Earth and solar system science in constraining the ages of a wide variety of rocks and minerals. Laser ablation inductively coupled plasma mass spectrometry (LA-ICP-MS) is one of the most popular techniques for $\mathrm{U}-\mathrm{Th}-\mathrm{Pb}$ geochronologic analysis. Currently, the significant matrix effects observed between different accessory minerals and the lack of high-quality standards for many minerals of interest are the major limitations of its geochronological applications. In this study, we investigated the effects of the addition of oxygen, nitrogen and water vapor before and after the ablation cell on the accuracy of the U-Th-Pb dating of different accessory minerals (e.g., zircon, wolframite, monazite, titanite, xenotime and bastnäsite) by LA-ICP-MS. We found that the addition of water vapor in the ablation chamber can significantly suppress the matrix effects on U-Th- $\mathrm{Pb}$ dating. The deviations of the measured ${ }^{206} \mathrm{~Pb} /{ }^{238} \mathrm{U}$ and ${ }^{208} \mathrm{~Pb} /{ }^{232} \mathrm{Th}$ ratios in these accessory minerals were significantly reduced from $10-24 \%$ to less than 1$2 \%$ when using zircon 91500 and/or NIST 610 glass as an external standard. The obtained results show that accurate and precise $\mathrm{U}-\mathrm{Pb}$ and $\mathrm{Th}-\mathrm{Pb}$ ages of different minerals (e.g., zircon, wolframite, monazite, titanite, xenotime and bastnäsite) can be obtained by using zircon 91500 and/or glass NIST 610 as the primary calibration standard in both $193 \mathrm{~nm}$ excimer laser and $213 \mathrm{~nm} \mathrm{Nd}$ : YAG laser ablation systems. This simple and effective water vapor-assisted non-matrix-matched laser ablation method helps to promote the geological application of accessory minerals U-Th- $\mathrm{Pb}$ geochronology. 